\title{
Strategic management in private and family businesses
}

\author{
Yuan Lu • Kevin Au • Mike W. Peng • Erming Xu
}

Published online: 12 June 2013

C) Springer Science+Business Media New York 2013

This Special Issue, taking five years to come to fruition, presents the latest research on strategic management in private and family businesses in Asia Pacific regions. Asia Pacific societies have a long history of private and family businesses. For example, a Chinese classic, Records of the Grand Historian (known by its Chinese name Shiji, which was written from 109 BC to 91 BC), includes a chapter, "Biographies of Usurers" (Huozhi liezhuan), which describes private business people such as merchants and handcraftsmen over 2,000 years ago. During China's Qing Dynasty (1644 to 1912), Chinese money merchants, who usually received investments from family members, already established subsidiaries in Japan. In India, Tata Group, established in 1860, is regarded as the number one family business in terms of size and scope. In Japan, a majority of large corporations today, such as Toyota and Suzuki, were actually developed from traditional family businesses.

There are some distinctions between private and family businesses. However, many people may think of these types of organizations as synonymous, since such organizations could be new ventures, small and medium-sized enterprises, and/or large corporations. "Private business" covers a wide range of enterprises that are

$\mathrm{Y} . \mathrm{Lu}(\bowtie) \cdot \mathrm{K} . \mathrm{Au}$

Department of Management, Chinese University of Hong Kong, Shatin, NT, Hong Kong e-mail: yuanlu@baf.msmail.cuhk.edu.hk

K. Au

e-mail: kevin@baf.cuhk.edu.hk

M. W. Peng

Jindal School of Management, University of Texas at Dallas, 800 West Campbell, SM 43, Richardson, TX 75080, USA

M. W. Peng

e-mail: apjmpeng@gmail.com

E. Xu

School of Business, Renmin University of China, No. 59 Zhong Guan Cun Street, Beijing 100872, China

E. Xu

e-mail: emxu@ruc.edu.cn 
founded, owned, and controlled by entrepreneurs or individual shareholders. "Family business" is more specific. It refers to a firm that is owned and managed by family members, although a family business may evolve into a private business after generations (Gersick, Davis, Hampton, \& Lansberg, 1997). Thus, the differences between private business and family business are likely to be in aspects of ownership structure and management control of strategic decision making.

In today's global economy, more private and family businesses from Asia Pacific regions have become well known globally. Examples can be found from traditional family businesses, such as Cheung Kong Group in Hong Kong, CP Group in Thailand, and chaebols in South Korea. Some of the newly emerged giants from mainland China, such as Huawei (the largest telecommunications equipment maker in the world) and Wanxiang Group (a global leader in the auto parts industry), are also private and family businesses.

With the rise of Asia Pacific economies, strategy research in this region increases. For instance, of the 13 papers in the Academy of Management Journal's 2000 Special Issue on Strategy in Emerging Economies (edited by Hoskisson, Eden, Lau, \& Wright, 2000), six were empirical studies in Asian societies. All of the six empirical papers in the Journal of Management Studies' 2005 Special Issue on Strategy Research in Emerging Economies (edited by Wright, Filatotchev, Hoskisson, \& Peng, 2005) were conducted in Asian countries (including one comparative study between Chinese and Romanian firms).

However, despite a growing attention to strategy research in Asia Pacific regions, our understanding of strategic management in private and family businesses seems to be insufficient (Jiang \& Peng, 2011; Liu, Yang, \& Zhang, 2012; Sharma \& Chua, 2013). Previous studies usually focus on entrepreneurial activities, such as venture start-up and development, ownership and governance structure, and relationship between local culture and management practices, but few have paid attention to strategy issues in these organizations. In response to the perceived gap in our knowledge, APJM launched this Special Issue. Overall, we received a total of 27 submissions. In this Special Issue, we feature 11 papers in addition to this Editorial and the Perspectives provided by Sharma and Chua (2013).

\section{Strategy in Asian organizations}

Strategy can be seen as a set of decisions and actions that are designated to exploit organizational competitive advantages in order to achieve pre-set objectives. Strategy scholars have long been fascinated by the relationships among strategy content, context, and processes; and/or an impact of such relations on firm performance (Hoskisson et al., 2000; Pettigrew, 2003; Wright et al., 2005). Previous studies in developed economies find that strategy-making processes vary according to the types of strategic content. For instance, a classical study of organizational decision making notes that certain key strategic issues such as new product development and reorganization matter the most (Hickson, Butler, Cray, Mallory, \& Wilson, 1986). In other words, whereas a strategy involves complex matters, such as individual or collective actors with various political interests, and when a strategy's outcome was 
uncertain because of dynamic and complexity of external environments, the strategy formation processes may become more complex than those processes with routine and straightforward matters, such as personnel. The rationale for these findings draws attention to the concept of bounded rationality - the rationality of actors as economic agents in strategy formation processes is bounded because information is limited due to costly information search and collection while their minds are bounded by limited capabilities.

Studies of strategic management in Asian societies have enriched the strategy literature by acknowledging the importance of contextual factors to strategy research (Li \& Peng, 2008; Lu, Tsang, \& Peng, 2008). As Xu and Meyer (2013) note, strategy research in emerging economies, including Asia Pacific regions, have encountered four main challenges in terms of (1) less efficient markets, (2) dominance of governments as both rule makers and players in economic activities, (3) preference for network-based behaviors, and (4) high risk and uncertainty caused by high volatility of key economic, political, and institutional variables. Interrelated with each other, all these relate to factors embedded in societal contexts. For instance, firm strategy formation and execution are largely shaped and elaborated by a society's institutional arrangements, which reflect institution-based preferences and mechanisms for resource allocations and control of organizational activities (Lu, 1996; Peng, 2003).

Thus, findings of strategy research in Asia Pacific regions have contributed greatly to the literature. Compared with earlier studies of organizations by identifying the importance of institutions in the formation of organizational structure and business practices (Orrù, Biggart, \& Hamilton, 1997; Whitley, 1990), recent research has further advanced the strategy literature through the examination of how contextual factors and institutional variables shape and influence firm strategy making and execution (Au, 2007; Chu, 2011; Filatotchev, Zhang, \& Piesse, 2011; Huang, Chen, \& Kao, 2012; Li \& Peng, 2008; Lu et al., 2008; Peng, Bhagat, \& Chang, 2010; Xu \& Meyer, 2013; Yang \& Terjesen, 2007).

Therefore, a strategist's rationality is not only bounded but also contingent on the context in which she or he makes decisions. The recognition that rationality is contextually dependent-or "contextual rationality" (Townley, 2008)-helps researchers incorporate contextual factors into their research design, data collection, and analysis. The distinctive characteristics of Asian Pacific regions as contexts are their long traditions of the state authoritative structures, late comer status in industrialization, diversity of religious beliefs, varieties of political systems, and a mix of transition versus emerging economies (Au, 2007; Carney, Gedajlovic, \& Yang, 2009; Globerman, Peng, \& Shapiro, 2011; Li \& Peng, 2008; Peng, 2003; Pye, 1985; Whitley, 1990). These contextual factors are assumed to introduce pre-set preferences and constraints on firm strategy formation and execution, especially in private and family businesses.

Then, in the Asia Pacific context, how do private and family businesses formulate strategies and implement them? How and to what extent do contextual factors influence the action and performance of private and family businesses? To address these questions, 11 papers published in this Special Issue present four major themes, as Table 1 exhibits. 
Table 1 Four research themes in this Special Issue

\begin{tabular}{|c|c|c|c|}
\hline Research themes & Papers in this Special Issue & $\begin{array}{l}\text { Types of sample } \\
\text { organization }\end{array}$ & $\begin{array}{l}\text { Empirical } \\
\text { context }\end{array}$ \\
\hline \multirow{5}{*}{$\begin{array}{l}\text { 1. Core competencies and } \\
\text { competitive advantages }\end{array}$} & Su \& Carney & Family business & China \\
\hline & Liang, Li, Yang, Lin, \& Zheng & Family business & China \\
\hline & Asaba & Family business & Japan \\
\hline & Deng, Hofman, \& Newman & Private business & China \\
\hline & Song \& Wang & $\begin{array}{l}\text { Private \& family } \\
\text { business }\end{array}$ & China \\
\hline \multirow{2}{*}{$\begin{array}{l}\text { 2. Trans-generational leadership/ } \\
\text { entrepreneurship }\end{array}$} & Au, Chiang, Birtch, \& Ding & Family business & Hong Kong \\
\hline & Saxena & Family business & India \\
\hline $\begin{array}{l}\text { 3. Alliance partner diversity and } \\
\text { firm performance }\end{array}$ & Pangarkar \& Wu & Private business & Singapore \\
\hline \multirow{3}{*}{$\begin{array}{l}\text { 4. Institutional impact on firm } \\
\text { behavior and performance }\end{array}$} & Su \& Lee, & Family business & Taiwan \\
\hline & Yiu, Su, \& Xu & Private business & China \\
\hline & Sauerwald \& Peng & $\begin{array}{l}\text { Private \& family } \\
\text { business }\end{array}$ & N/A \\
\hline
\end{tabular}

\section{Themes of this Special Issue}

Overall, four themes emerge: (1) Core competencies and competitive advantages possessed by private and family businesses, (2) trans-generational leadership and entrepreneurship, (3) alliance partner diversity and firm performance, and (4) institutional impact on firm behavior and performance.

Focusing on a mainstream strategy research topic, the first theme identifies the unique core competencies possessed or leveraged by private and family businesses. Five papers under this theme examine competitive advantages of firms from China and Japan. A major theoretical base is the resource-based view (RBV), while authors also explore multiple perspectives such as agency theory and the institution-based view. There are numerous interesting findings revealed by these papers. They include unique social capital possessed by family businesses where tacit knowledge is shared between family members ( $\mathrm{Su} \&$ Carney, 2013); the influences of family members involvement in board versus management on firm innovation performance (Liang, Li, Yang, Lin, \& Zheng, 2013); patent investment of family owners in innovation for a long term return (Asaba, 2013); ownership concentration as a strong moderating effect on product innovation (Deng, Hofman, \& Newman, 2013); and the relationship between different types of information as critical resources and building firm competitive advantages (Song \& Wang, 2013).

A second theme examined in this Special Issue is about trans-generational change of leadership and entrepreneurship - (1) a case study by Au, Chiang, Birtch, and Ding (2013) in Hong Kong and (2) an overview by Saxena (2013) in India. Transformation of leadership from one generation to another may be one of the mostly attractive topics in family business research. On the one hand, a family business needs to identify the most appropriate candidate to succeed the existing leader's position. On 
the other hand, its selection of candidates may be limited within the family members as it must retain control over the management. Employing the RBV and learning theory, Au et al. (2013) develop propositions that highlight the key variables for further research in this area. Focusing on business groups, Saxena (2013) extends a psychoanalytic framework to shed light on trans-generational succession challenges in India.

A third theme discusses how a diverse portfolio of alliance partners influences private start-up firms to achieve a rapid growth. One paper by Pangarkar and Wu (2013) falls into this category. They apply the RBV and learning perspectives to test the relationship between partner diversify and performance of start-up firms. They find that partner diversity helps start-up firms to enhance performance, since it not only enables them to gain critical resources and skills but also makes them avoid environmental uncertainties through cooperation with key environmental constituents.

The last theme turns attention to the impact of institutional factors on firm behavior and performance. Su and Lee (2013) examine the influence of institutional change on the role of outside directors in family business risk taking. They report that in Taiwan, outside directors indeed reduce firms' risk taking but this relationship is weakened after the firm goes to public. Yiu, Su, and $\mathrm{Xu}$ (2013) focus on the relationship between informal finance and performance of private businesses in China's transition economy. Since the resource allocation mechanisms in China are dominated by the state that is in favor of state-owned enterprises, private enterprises find it difficult to access critical resources, such as capital. Under such circumstances, informal financing becomes important to private enterprises. Finally, Sauerwald and Peng (2013) focus on how informal institutions impact principal-principal conflicts, which are often found in private and family businesses. They characterize much of the institution-based view of corporate governance (Young et al., 2008) as a "formal institution-based view," and complement and extending existing research by an explicit focus on informal institutions.

Overall, the papers in this Special Issue, through the four themes, have significantly advanced our understanding of strategic management in private and family businesses in Asia Pacific regions. The RBV, the institution-based view, learning perspective, and agency theory have emerged as four main theoretical frameworks for strategy research in this area. It seems that each of these four theories has different strengths for developing hypotheses and data analysis. For instance, the RBV and learning perspective are more powerful to research on trans-generation of leadership in family business and strategic alliances, while the RBV and the institution-based view offer greater insights centered on external control and resource allocation to sample organizations and construction of core competencies within firms. Moreover, the agency theory and the institution-based view can be integrated to analyze corporate governance and directorship.

\section{Conclusion}

To sum up, we believe that the distinctive characteristics of the Asia Pacific context and the long history and traditions of private and family businesses will provide strategy researchers wonderful opportunities to identify and test varieties of 
hypotheses and propositions among strategy content, context, and processes. Beyond this Special Issue, our ultimate goal is to propel research grounded in an Asia Pacific context to contribute to the global discourse of strategic management in private and family businesses.

Acknowledgment We thank all the authors who submitted their work and all the reviewers who assisted us. We appreciate the contributions made by Renmin University of China (host of our Special Issue Conference in Beijing in July 2011) and The Chinese University of Hong Kong (supporter of this Conference). Finally, we thank Hua Song and his preparation team (Hai Guo, Nan Yao, Qi Feng, Ying Zhang, Jing Li, and Huani Jiao) for making the conference happen, and Rachel Pinkham for editorial assistance.

\section{References}

Asaba, S. 2013. Patent investment of family firms in the Japanese electric machinery industry. Asia Pacific Journal of Management, 30(this issue, doi:10.1007/s10490-012-9319-3).

$\mathrm{Au}$, K. 2007. Self-confidence does not come isolated from the environment. Asia Pacific Journal of Management, 24(4): 491-496.

Au, K., Chiang, F. F. T., Birtch, T. A., \& Ding, Z. 2013. Incubating the next generation to venture: The case of a family business in Hong Kong. Asia Pacific Journal of Management, 30(this issue, doi:10.1007/ s10490-012-9331-7).

Carney, M., Gedajlovic, E., \& Yang, X. 2009. Varieties of Asian capitalism: Toward an institutional theory of Asian enterprise. Asia Pacific Journal of Management, 26(3): 361-380.

Chu, W. 2011. Family ownership and firm performance: Influence of family management, family control, and firm size. Asia Pacific Journal of Management, 28(4): 833-851.

Deng, Z., Hofman, P. S., \& Newman, A. 2013. Ownership concentration and product innovation in Chinese private SMEs. Asia Pacific Journal of Management, 30(this issue, doi:10.1007/s10490-012-9301-0).

Filatotchev, I., Zhang, X., \& Piesse, J. 2011. Multiple agency perspective, family control, and private information abuse in an emerging economy. Asia Pacific Journal of Management, 28(1): 69-93.

Gersick, K., Davis, J., Hampton, M., \& Lansberg, I. 1997. Generation to generation: Life cycles of the family business. Boston: Harvard Business School Press.

Globerman, S., Peng, M. W., \& Shapiro, D. M. 2011. Corporate governance and Asian companies. Asia Pacific Journal of Management, 28(1): 1-14.

Hickson, D., Butler, R., Cray, D., Mallory, G., \& Wilson, D. 1986. Top decisions: Strategic decisionmaking in organizations. San Francisco, CA: Jossey-Bass.

Hoskisson, R., Eden, L., Lau, C. M., \& Wright, M. 2000. Strategy in emerging economies. Academy of Management Journal, 43: 249-267.

Huang, Y., Chen, A., \& Kao, L. 2012. Corporate governance in Taiwan: The nonmonotonic relationship between family ownership and dividend policy. Asia Pacific Journal of Management, 29(1): 39-58.

Jiang, Y., \& Peng, M. W. 2011. Are family ownership and control in large firms good, bad, or irrelevant?. Asia Pacific Journal of Management, 28(1): 15-39.

Li, Y., \& Peng, M. W. 2008. Developing theory from strategic management research in China. Asia Pacific Journal of Management, 25(3): 563-572.

Liang, Q., Li, X., Yang, X., Lin, D., \& Zheng, D. 2013. How does family involvement affect innovation in China?. Asia Pacific Journal of Management, 30(this issue, doi:10.1007/s10490-012-9320-x).

Liu, W., Yang, H., \& Zhang, G. 2012. Does family business excel in firm performance? An institutionbased view. Asia Pacific Journal of Management, 29(4): 965-987.

Lu, Y. 1996. Management decision making in Chinese enterprises. London: Macmillan.

Lu, Y., Tsang, E. W. K., \& Peng, M. W. 2008. Knowledge management and innovation strategy in the Asia Pacific: Toward an institution-based view. Asia Pacific Journal of Management, 25(3): 361-374.

Orrù, M., Biggart, N. W., \& Hamilton, G. G. (Eds.). 1997. The economic organization of East Asian capitalism. London: Sage.

Pangarkar, N., \& Wu, J. 2013. Alliance formation, partner diversity, and performance of Singapore startups. Asia Pacific Journal of Management, 30(this issue, doi:10.1007/s10490-012-9305-9). 
Peng, M. W. 2003. Institutional transitions and strategic choices. Academy of Management Review, 28: 275-296.

Peng, M. W., Bhagat, R., \& Chang, S.-J. 2010. Asia and global business. Journal of International Management Studies, 41: 373-376.

Pettigrew, A. 2003. Strategy as process, power, and change. In S. Cummings \& D. Wilson (Eds.). Editors, images of strategy: 301-330. Oxford: Blackwell.

Pye, L. 1985. Asian power and politics: The cultural dimensions of authority. Cambridge: Harvard University Press.

Sauerwald, S., \& Peng, M. W. 2013. Informal institutions, shareholder coalitions, and principal-principal conflicts. Asia Pacific Journal of Management, 30(this issue, doi:10.1007/s10490-012-9312-x).

Saxena, A. 2013. Transgenerational succession in business groups in India. Asia Pacific Journal of Management, 30(this issue, doi:10.1007/s10490-013-9342-z).

Sharma, P., \& Chua, J. H. 2013. Asian family enterprises and family business research. Asia Pacific Journal of Management, 30(this issue, doi:10.1007/s10490-013-9350-z).

Song, H., \& Wang, L. 2013. The impact of private and family firms' relational strength on financing performance in clusters. Asia Pacific Journal of Management, 30(this issue, doi:10.1007/s10490-012-9316-6).

Su, E., \& Carney, M. 2013. Can China's family firms create intellectual capital?. Asia Pacific Journal of Management, 30(this issue, doi:10.1007/s10490-012-9302-z).

$\mathrm{Su}$, W., \& Lee, C.-Y. 2013. Effects of corporate governance on risk taking in Taiwanese family firms during institutional reform. Asia Pacific Journal of Management, 30(this issue, doi:10.1007/s10490-012-9292-x).

Townley, B. 2008. Reason's neglect: Rationality and organizing. Oxford: Oxford University Press.

Whitley, R. 1990. Eastern Asian enterprise structures and the comparative analysis of forms of business organization. Organization Studies, 11: 47-74.

Wright, M., Filatotchev, I., Hoskisson, R., \& Peng, M. W. 2005. Strategy research in emerging economies: Challenging the conventional wisdom. Journal of Management Studies, 42: 1-33.

Xu, D., \& Meyer, K. 2013. Linking theory and context: 'Strategy research in emerging economies' after Wright et al. (2005). Journal of Management Studies, in press.

Yang, X., \& Terjsen, S. 2007. In search of confidence: Context, collaboration and constraints. Asia Pacific Journal of Management, 24(4): 497-507.

Yiu, D. W., Su, J., \& Xu, Y. 2013. Alternative financing and private firm performance. Asia Pacific Journal of Management, 30(this issue, doi:10.1007/s10490-012-9303-y).

Young, M. N., Peng, M. W., Ahlstrom, D., Bruton, G. D., \& Jiang, Y. 2008. Corporate governance in emerging economies: A review of the principal-principal perspective. Journal of Management Studies, 45: 196-220.

Yuan Lu (PhD, Aston University) is a professor of management at the Chinese University of Hong Kong. His research interests are corporate social responsibilities, discourse analysis, and leadership succession.

Kevin Au (PhD, University of British Columbia) is an associate professor of management at the Chinese University of Hong Kong. His research interests are international management, entrepreneurship, family business, and social network.

Mike W. Peng ( $\mathrm{PhD}$, University of Washington) is the Jindal Chair of Global Strategy at the Jindal School of Management, University of Texas at Dallas; a National Science Foundation CAREER Award winner; and a Fellow of the Academy of International Business. His research interests are global strategy and international business, with a focus on the institution-based view.

Erming Xu (PhD, Renmin University of China) is a professor of management at Renmin University of China. His research interests are strategic innovation and entrepreneurship, with a focus on institutional entrepreneurship. 